\title{
SIMULATING THE SENSITIVITY OF UNDERGROUND VENTILATION NETWORKS TO FLUCTUATING AMBIENT CONDITIONS
}

\author{
R. Fair ${ }^{1 *}$, J.H. van Laar $^{2}$, K. Nell ${ }^{1}$, D. Nell ${ }^{1}$ \& E.H. Mathews ${ }^{1}$
}

\section{ARTICLE INFO}

\section{Article details}

Presented at the $32^{\text {nd }}$ annual conference of the Southern African Institute for Industrial Engineering (SAIIE), held from 4-6 October 2021 in Muldersdrift, South Africa.

Available online

29 Nov 2021

Contact details

Corresponding author

rfair@rems2.com

\section{Author affiliations}

1 Centre for Research and Continued Engineering Development (CRCED), North West University, South Africa

2 Department of Industrial Engineering, University of Stellenbosch, South Africa

\section{ORCID® identifiers}

R. Fair1

https://orcid.org/0000-0002-5286-9045

J.H. van Laar

https://orcid.org/0000-0003-0457-328X

K. Nell

https://orcid.org/0000-0002-0670-045X

D. Nell

https://orcid.org/0000-0002-2817-9343

E.H. Mathews

https: / /orcid.org/0000-0001-5425-6368

DOI

http://dx.doi.org/10.7166/32-3-2616

\section{ABSTRACT}

The weather directly impacts ventilation systems, especially large industrial systems found in underground mines. Underground mine ventilation systems have high cost implications that add to the financial strains and uncertainties of future mining operations. In addition, the dynamic nature of underground ventilation systems makes the accurate prediction of underground conditions extremely difficult using traditional steady-state methods. Therefore, improved prediction methods of dynamic underground environmental conditions are needed to ensure cost-effective ventilation systems. This paper investigates simulating the sensitivity that underground ventilation systems have to fluctuating ambient conditions. Simulation software was applied to a case study on a gold mine in South Africa. The results showed that transient software can now be applied to entire mine ventilation systems, and can improve predicting the underground environment because of fluctuating ambient conditions.

\section{OPSOMMING}

Die weer het 'n direkte impak op ventilasiestelsels, veral by groot industriële stelsels soos in gebruik in ondergrondse myne. Ondergrondse mynventilasie-stelsels het hoë koste-implikasies wat bydra tot die finansiële druk en onsekerheid van toekomstige mynbedrywighede. Die dinamiese aard van ondergrondse mynventilasiestelsels bemoeilik die voorspelling van die ondergrondse toestande met tradisionele, gestadigdetoestand metodes aansienlik. Daarom word verbeterde voorspellingsmetodes van die dinamiese ondergrondse omgewingstoestande benodig; dit mag ook die kostedoeltreffendheid van mynventilasiestelsels verseker. Hierdie artikel ondersoek die moontlikheid om die faktore wat die verandering van ondergrondse omgewingstoestande beïnvloed, te simuleer. Simulasie sagteware is toegepas in 'n gevallestudie van 'n goudmyn in Suid-Afrika. Die resultate toon dat die oorgangsgedrag gesimuleer kan word en dat dit gebruik kan word om die veranderende omgewingstoestande te voorspel.

1

INTRODUCTION

\subsection{Background}

Underground mine ventilation systems provide an underground working environment that is conducive to productive work [1], [2]. In South Africa, the Mine Health and Safety Council enforces environmental standards [3].

These ventilation systems generally consist of underground tunnels in which ventilation equipment controls the airflow [2]. Figure 1 illustrates a simplified ventilation system on a conventional underground mine. 


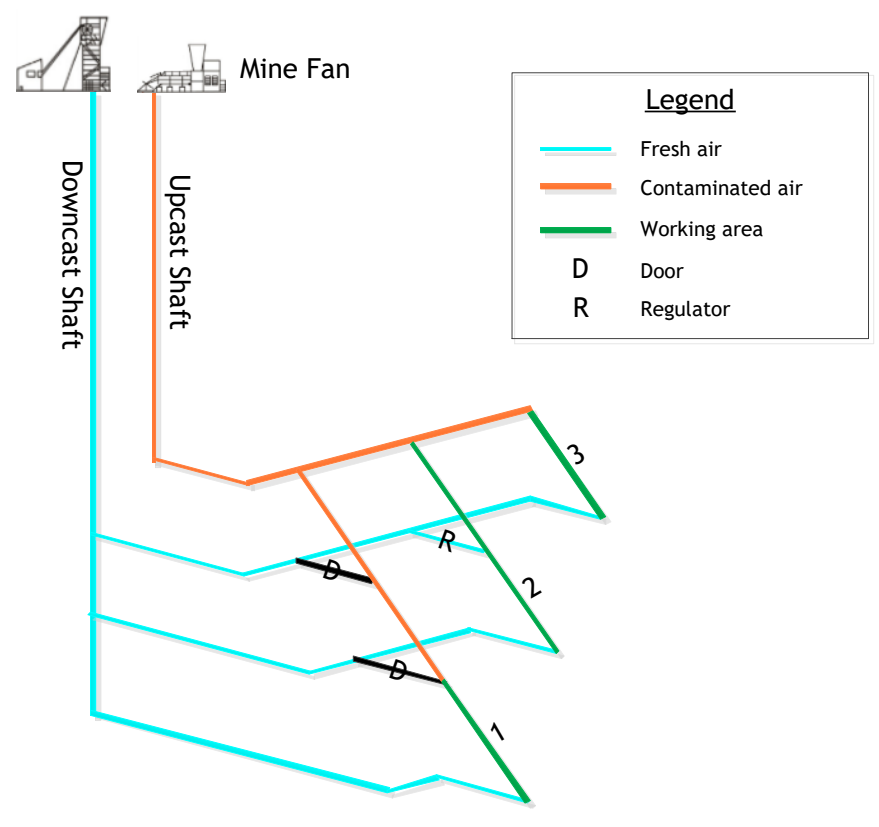

Figure 1: Simplified mine ventilation system (adapted from [2])

The amount of heat transferred to the ventilation system increases as the mining network expands to both new depths and extended distances from the shaft. Underground mines have many potential heat sources, such as [4]:

- $\quad$ Strata heat (geothermal gradient),

- Auto-compression,

- Machinery,

- Human metabolism,

- Oxidation,

- $\quad$ Blasting, and

- $\quad$ Fissure water.

These heat sources increase the limiting temperature of the working areas. Consequently, cooling systems are needed to mitigate the heat and achieve required temperatures. The cooling requirements are balanced with the cost of refrigeration when planning a ventilation system [5].

The high cost implications of ventilating mining networks add to the financial strains and uncertainties of the future of mining operations [6]. Industry 4.0 is becoming a crucial paradigm to ensure that the mining sector remains profitable [7]. Tools such as real-time climatic monitoring systems and simulations are used for ventilation system management [6], [8], [9], [10].

\subsection{Dynamic nature of mine ventilation systems}

The main intake of an underground ventilation system is directly from the ambient environment. Fluctuating ambient temperatures can have a significant impact on underground conditions [11]. The changing ambient conditions and the dynamic nature of an underground mine result in a complex system that is never steady-state. The heat exchange between the ventilation air and the underground rock is always transient [12].

Figure 2 shows the intake dry-bulb (DB) temperatures of a South African mine and the DB temperatures at $1290 \mathrm{~m}$ below the surface over 24 hours. The decrease in the temperature fluctuation as the air travels down the mine is known as the thermal damping effect (TDE). The time lag in temperature peaks as the air travels down the mine is the thermal flywheel effect (TFE) [12]. 


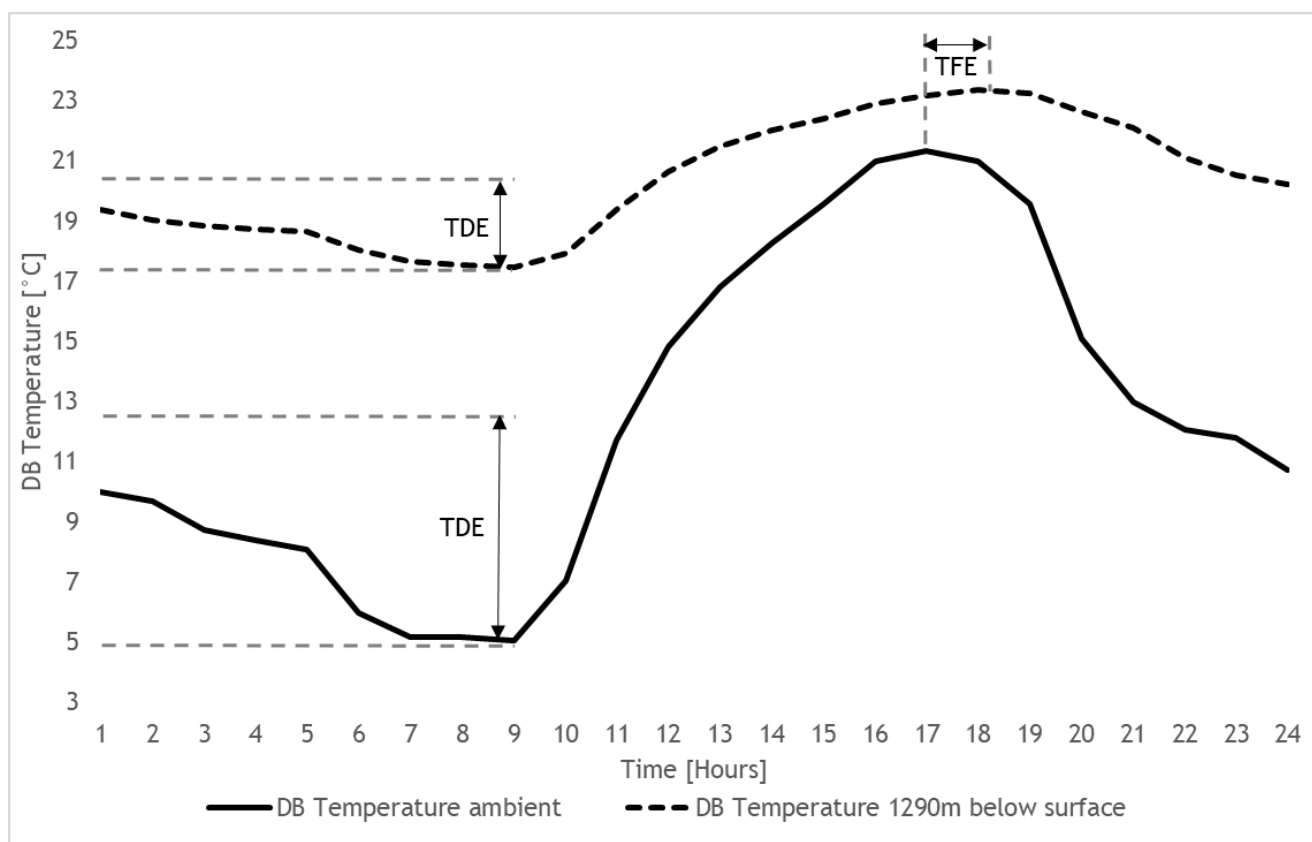

Figure 2: DB temperature damping at $1290 \mathrm{~m}$ below surface over a 24h period

\subsection{Mine ventilation simulation software}

Simulation software is widely used on mine ventilation systems [13]. These simulation programs are a crucial part of mine ventilation systems' planning and energy optimisation processes [10], [14]. A wide range of software is available, a number of which are commercially available, such as [13], [15]:

- $\quad$ Process Toolbox (PTB),

- VentSim,

- Vuma-3D,

- ClimSim,

- VnetPC,

- MineFire,

- DuctSIM,

- VentGraph,

- MULTIFLUX,

- VenPri, and

- 3D-Canvent.

Most of these software packages have an intuitive setup with a three-dimensional (3D) visualiser to allow for the rapid assessment of underground network sizing [13].

Studies have shown the limitations of steady-state analysis in underground ventilation networks [11], [12]. Steady-state simulations tend to over-predict the high temperatures and under-predict the low temperatures that are traditionally used to plan future underground operations [11]. Therefore, timedependent or transient simulation software is required to simulate the dynamic heat transfer processes such as the TDE and the TFE [16], [17].

Few simulation software packages are capable of incorporating true transient heat exchange calculations into an entire mine ventilation system [11], [17], [18]. The MULTIFLUX model can simulate the TDE and TFE, but it is not yet commercially available, and it has not been applied to an entire mine ventilation network [12]. VUMA-transient was developed to simulate temperature variations, but no literature was found on the application thereof to an entire mining network [19], [20]. PTB is a thermodynamic simulation software that is capable of incorporating transient heat exchange processes, but it has not yet been applied to an entire mine ventilation system [15]. 


\section{$1.4 \quad$ Need and objective}

With the limitations of the steady-state simulation of ventilation systems seen in the literature, there is a need to model the entire ventilation system of an underground mine using transient simulations. This study will construct and calibrate a transient simulation of a complete underground gold mine ventilation system in South Africa. Ambient conditions will be used as an input to predict underground temperatures, accounting for complex heat exchange processes and the sensitivity of an underground mine ventilation network.

The accuracy of the underground temperature predictions will be compared with that of steady-state analysis. This will determine whether the use of transient simulation could improve the prediction of underground limiting-temperatures used in life-of-mine planning and optimisation processes.

\section{METHODOLOGY}

\subsection{Technical overview of Process Toolbox}

The thermohydraulic simulation software Process Toolbox (PTB) was used for this study. PTB is a onedimensional computational fluid dynamics (CFD) code that is capable of solving complex thermo-hydraulic networks, such as mine ventilation systems [15], [21], [22].

The software has a 3D interface that assists with the intuitive construction and calibration of ventilation systems. The simulation is constructed on the actual digital layouts to ensure accurate dimensions of the underground system.

The PTB code solves steady-state and transient solutions of energy, mass, and momentum balances for any number of periods and period sizes. Transient flow is solved with a quasi-steady-state semi-implicit algorithm. The pressure matrix is linearised to guarantee convergence for every step so that no iterations are required. This is valuable in industrial scenarios such as mine ventilation systems [15].

The components of PTB are designed to represent an underground mine ventilation system as closely as possible. Actual rock heat transfer properties are used to ensure that the heat capacity of the simulation is as accurate as possible. Design specifications and measurements are used to calibrate underground ventilation equipment such as fans and heat exchangers.

\subsection{Method}

\subsubsection{Data acquisition}

Continuous and accurate data is required for the calibration of transient heat transfer processes [17]. A wide range of technology is available that allows for the continuous monitoring of an underground ventilation network. Nell et al. [6] described the different levels of detail to which a mine ventilation system can be instrumented. Increased levels of detail would result in the increased accuracy of the simulation.

Mines that have not yet been instrumented with data collection technology require manual measurements. Hand-held data-loggers that allow for the continuous monitoring of temperature, humidity, and barometric pressure are available [11], [12], [17]. The number of data measurement points is mainly dependent on the mine ventilation system, the instrumentation available, and the required outcomes of the simulations [10]. In general, the following information is required for all main airways and working areas:

- $\quad$ Air mass flow $(\mathrm{kg} / \mathrm{s})$,

- $\quad$ Dry-bulb $(\mathrm{DB})$ temperature $\left({ }^{\circ} \mathrm{C}\right)$, and

- Wet-bulb (WB) temperature $\left({ }^{\circ} \mathrm{C}\right)$.

The information about and specification of all environmental control devices should be collected from mining personnel and measurements. The simulation is built on the digital layouts of the underground mining network. 


\subsubsection{Calibration and verification}

The complex nature of an underground ventilation system means that an iterative approach is required to calibrate the simulation model [10]. First, the underground system model must be constructed as accurately as possible in respect of the actual system dimensions. Second, all known component parameters must be programmed into the model. The calibration process can then be broken down into the following steps:

1. Build ventilation system in digital layouts.

2. Use continuous measured ambient data as inputs to air boundaries on the surface.

3. Simulate the model.

4. Compare measured points in the mine with the simulation results.

5. Adjust calibration parameters.

6. Repeat steps 2-4 until the desired accuracy is achieved.

The performance of the model is calculated using the mean square error (MSE) and the coefficient of determination $\left(\mathrm{R}^{2}\right)$ [17]. The MSE is calculated with Equation 1:

$$
M S E=\left(\sum_{i=1}^{n}\left(\hat{y}_{i}-y_{i}\right)^{2}\right) / n
$$

Here:

- $\quad \hat{y}_{i}$ is the simulation result,

- $\quad y_{i}$ is the measured data, and

- $\quad n$ is the number of data points.

PTB has the functionality to switch to a steady-state solver. This allows the simulation to solve for the same parameters and input conditions.

\section{RESULTS AND DISCUSSION}

The results show how the method is applied to a real-life case study on an underground gold mine ventilation system. The calibrated results are shown and compared with those of traditional methods.

\subsection{Case study overview}

A gold mine in Free State Province, South Africa, was selected as a case study. It is mining at an average depth of $1290 \mathrm{~m}$ underground. It follows a conventional mining setup, as shown in Figure 1.

The mine ventilation system has two downcast shafts and a single upcast shaft, and does not have secondary cooling systems. Therefore, the environmental conditions recorded underground are only influenced by the ambient conditions and by the heat sources in the underground network.

\subsection{Data acquisition}

At the time of this study, the mine did not have ventilation instrumentation installed, and all data had to be collected with hand-held instruments. Continuous loggers were placed on the surface and underground to measure the change in temperature as the air flowed through the mine ventilation system.

A logger was placed $1290 \mathrm{~m}$ below the surface on the main working level. The difference between surface temperatures and underground temperatures will be due to heat sources in the ventilation system. This indicates how sensitive the mine is to changing ambient conditions. Figure 3 illustrates the ambient and underground DB temperatures and WB temperatures recorded over three days. 


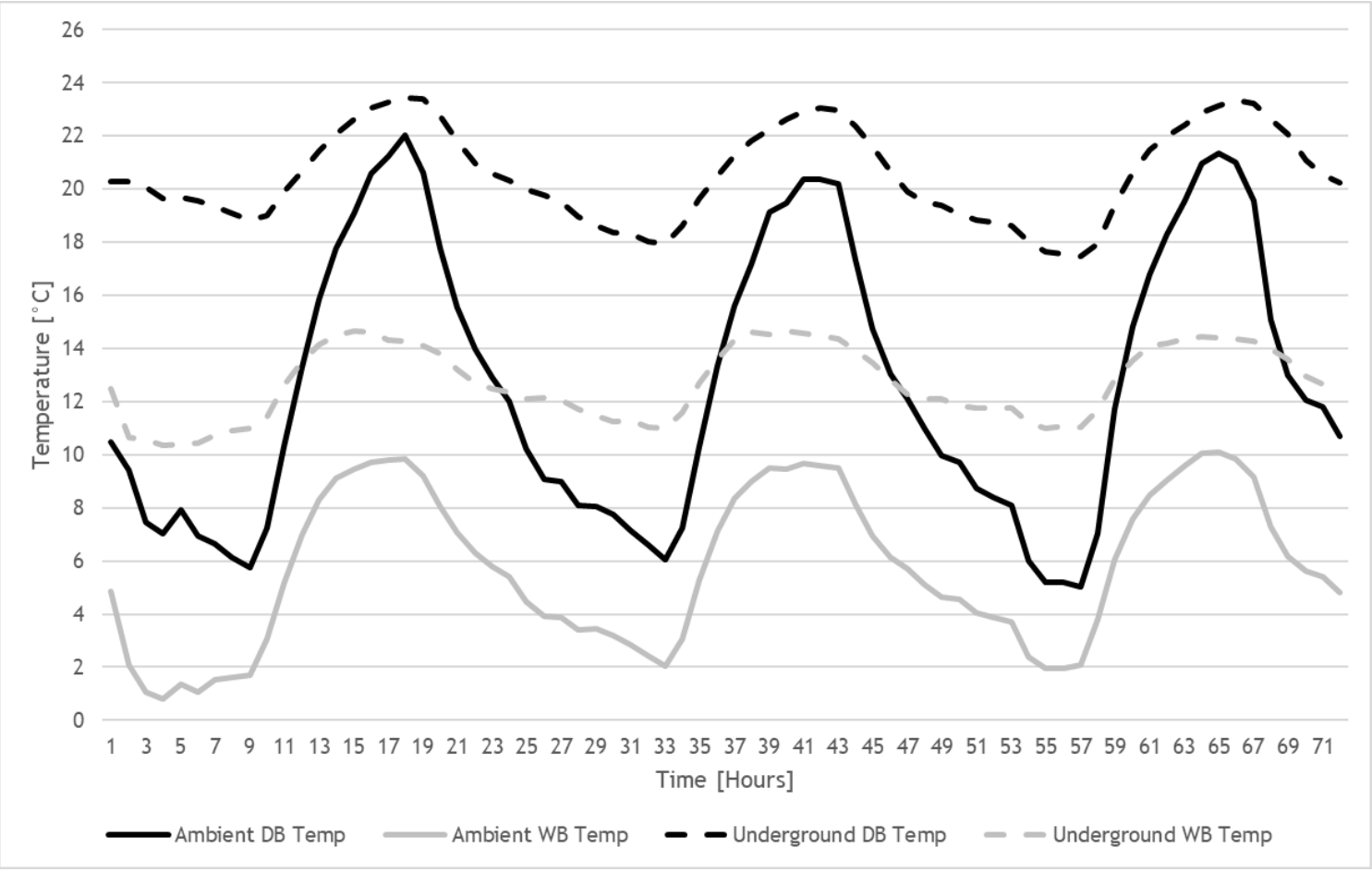

Figure 3: Ambient and underground temperatures at the case study mine

The simulation software was used to build the ventilation system according to the mine plan. All known parameters were programmed into the model. Figure 4 shows a screenshot of the PTB ventilation system model of the mine.

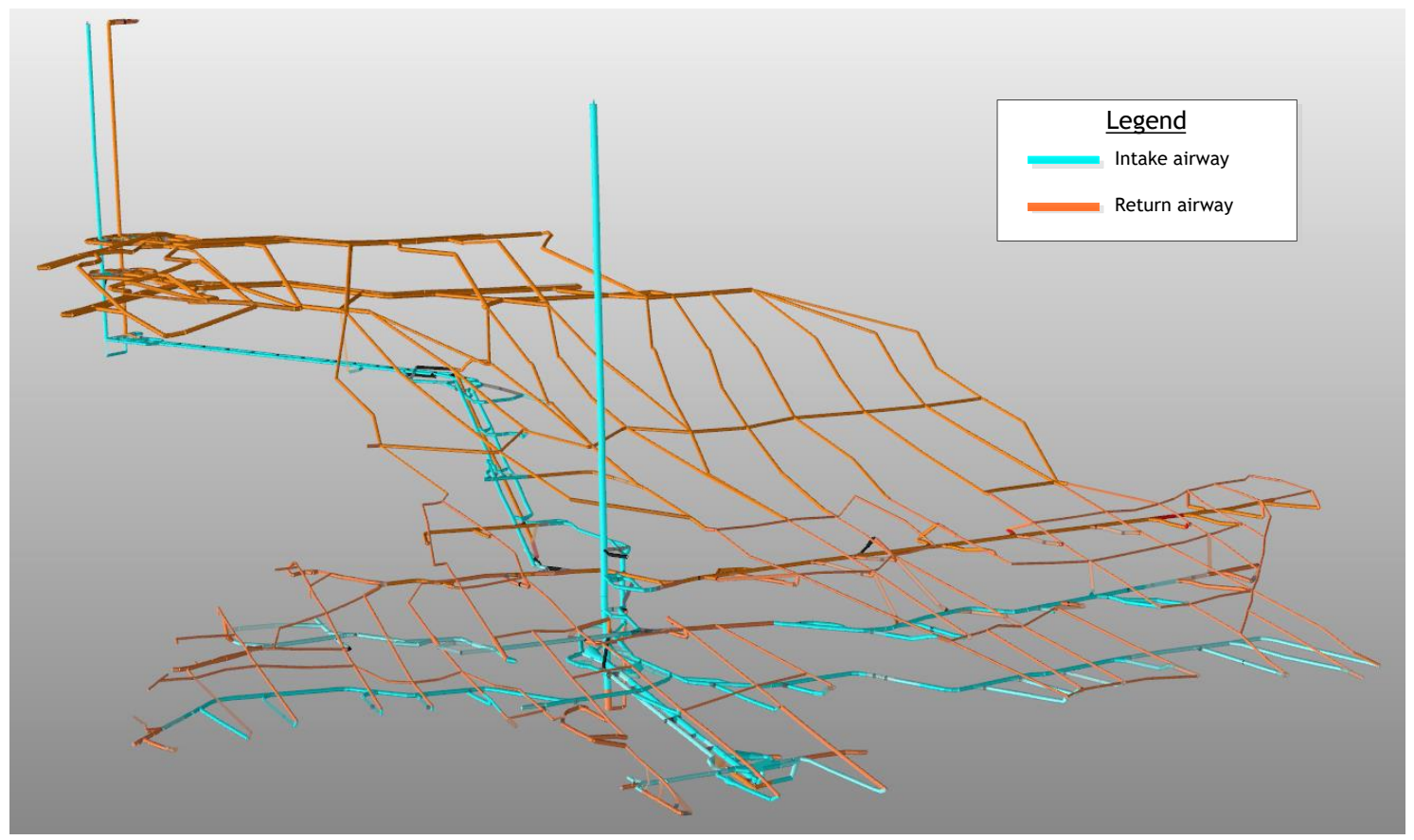

Figure 4: PTB ventilation simulation 


\subsection{Calibration and verification}

The temperature data was collected over three weeks. This provided a suitable temperature history that allowed for accurate heat exchange [18]. The iterative process discussed in Section 2.2.2 was followed to calibrate the model.

The measured air mass flow through the ventilation network was compared with the simulation results at the same points. The MSE was calculated to be 0.77 , with a maximum error of $2.11 \mathrm{~kg} / \mathrm{s}$.

The measured $\mathrm{DB}$ and $\mathrm{WB}$ temperatures on the main working level underground were compared with the simulated $D B$ and WB temperatures. Figure 5 illustrates how the simulated temperature predictions compared with the actual measurements. The transient simulation was able to incorporate the TDE and TFE.

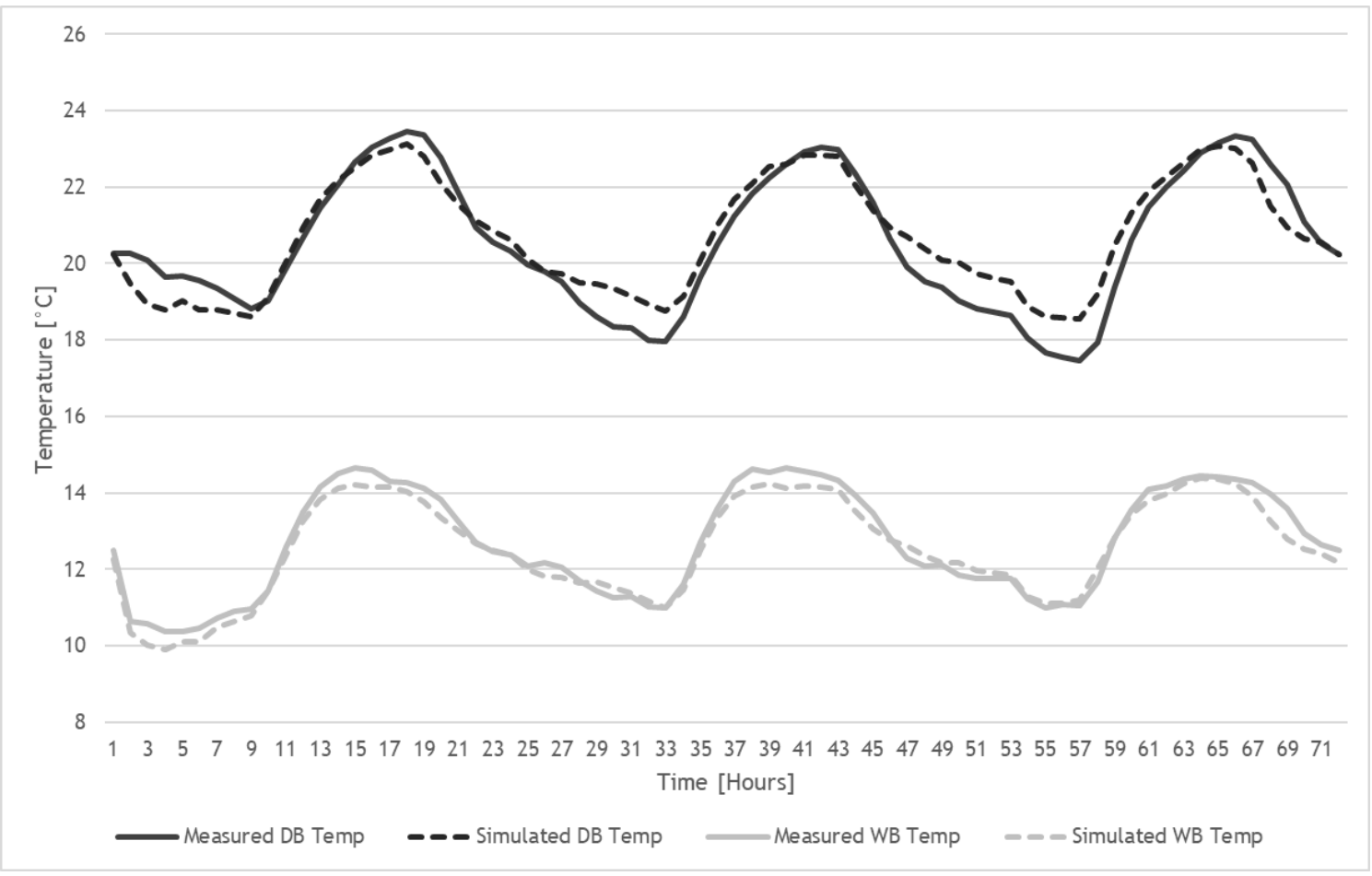

Figure 5: Underground temperature comparison using transient simulation

The simulation predicted the DB temperature with a performance accuracy of $M S E=0.38, R^{2}=0.99$, and a maximum error of $1.5^{\circ} \mathrm{C}$. The WB temperature performance was even better, with an MSE $=0.09, \mathrm{R}^{2}=0.97$ and a maximum error of $0.8^{\circ} \mathrm{C}$. Table 1 shows a summary of the transient simulation performance. These results show that it is possible to apply transient ventilation simulation to an entire mine ventilation system.

Table 1: Summary of simulation performance

\begin{tabular}{|l|c|c|c|}
\hline & MSE & $\mathbf{R}^{\mathbf{2}}$ & Maximum error \\
\hline Air mass flow & 0.77 & - & 2.11 \\
\hline DB temperature (transient) & 0.38 & 0.99 & 1.53 \\
\hline WB temperature (transient) & 0.09 & 0.97 & 0.79 \\
\hline
\end{tabular}

Maximum temperatures are traditionally used to predict limiting underground temperatures [11]. The results showed the following maximum underground temperatures:

- $\quad$ DB temperature of $23.14^{\circ} \mathrm{C}\left(0.30^{\circ} \mathrm{C}\right.$ lower than actual $)$

- $\quad$ WB temperature of $14.39^{\circ} \mathrm{C}\left(0.27^{\circ} \mathrm{C}\right.$ lower than actual $)$ 


\subsection{Comparison with steady-state simulation}

From the literature, there are limitations to steady-state ventilation analysis. Quasi-steady-state simulations have been shown to provide more accurate results when compared with steady-state methods [11], [12].

The ventilation model was re-simulated with traditional steady-state analysis. The maximum ambient temperatures shown in Figure 3 were used to determine the limiting mine temperatures. The results showed the following maximum temperatures at a depth of $1290 \mathrm{~m}$ :

- $\quad$ DB temperature of $26.09^{\circ} \mathrm{C}\left(2.65^{\circ} \mathrm{C}\right.$ higher than actual $)$

- $\quad$ WB temperature of $16.13^{\circ} \mathrm{C}\left(1.47^{\circ} \mathrm{C}\right.$ higher than actual $)$

The ventilation model was re-simulated with quasi-steady-state analysis. Figure 6 illustrates the transient and quasi-steady-state simulation results compared with the transient prediction and actual measurements.

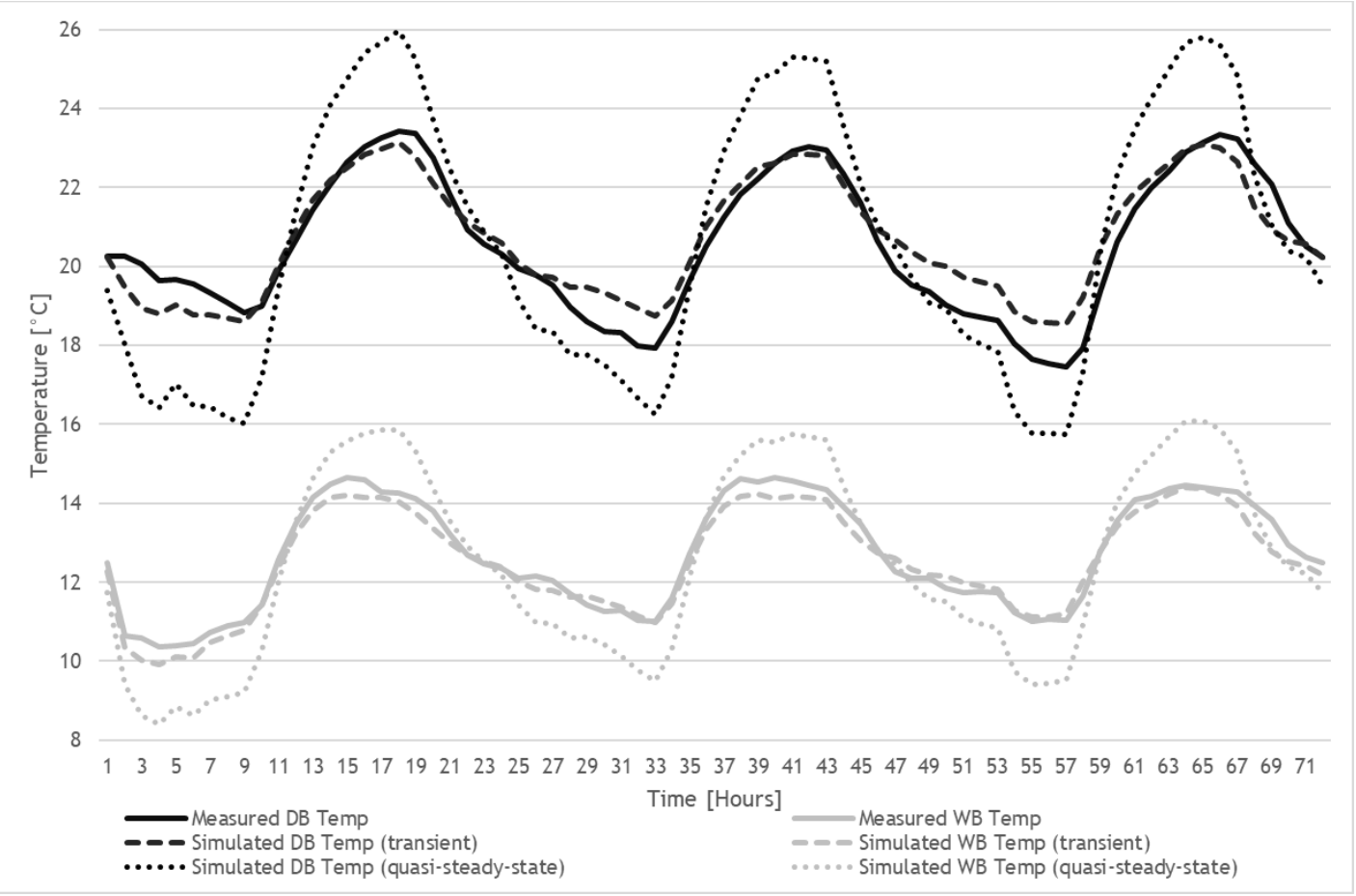

Figure 6: Comparison of transient and quasi-steady-state simulations

Comparing the steady-state and quasi-steady-state analyses showed a slight improvement in predictions. The results showed the following maximum temperatures at a depth of $1290 \mathrm{~m}$ :

- $\quad$ DB temperature of $25.98^{\circ} \mathrm{C}\left(2.54^{\circ} \mathrm{C}\right.$ higher than actual $)$

- WB temperature of $16.08^{\circ} \mathrm{C}\left(1.42^{\circ} \mathrm{C}\right.$ higher than actual $)$

Compared with the transient solution, the quasi-steady-state solution had a higher MSE, with 3.03 for the DB temperature and 1.15 for the WB temperature. The quasi-steady-state model had a maximum error of 3.34 for $\mathrm{DB}$ temperature and 1.95 for WB temperature. A summary comparison of the simulation performance is shown in Table 2.

Table 2: Comparison of transient and quasi-steady-state simulation performance

\begin{tabular}{|l|c|c|c|}
\hline & MSE & $\mathbf{R}^{\mathbf{2}}$ & Maximum error \\
\hline Air mass flow & 0.77 & - & 2.11 \\
\hline DB temperature (transient) & 0.38 & 0.99 & 1.53 \\
\hline DB temperature (quasi-steady) & 3.03 & 0.98 & 3.34 \\
\hline WB temperature (transient) & 0.09 & 0.97 & 0.79 \\
\hline WB temperature (quasi-steady) & 1.15 & 0.99 & 1.95 \\
\hline
\end{tabular}




\subsection{Discussion}

The results showed that the simulation could accurately predict the underground environment as a result of fluctuating ambient temperatures. The transient simulation was then compared with traditional steadystate analysis. This showed that the transient simulation had a clear advantage when simulating complex heat transfer processes such as the TDE and TFE.

From the results and the literature, steady-state simulations over-predict high temperatures and underpredict low temperatures. Inaccurate predictions have a detrimental impact on the life-of-mine planning and optimisation of a ventilation system, because cooling requirements are determined from the predicted underground temperatures.

The over-prediction of underground temperatures would result in over-predicted cooling requirements. In this study, the steady-state analysis over-predicted the limiting underground temperatures by $2.65^{\circ} \mathrm{C}$ for DB and by $1.47^{\circ} \mathrm{C}$ for WB compared with the actual temperatures. This would result in $1.1 \mathrm{MW}$ of overcooling when planning or optimising this ventilation system. $1.1 \mathrm{MW}$ of cooling on a typical bulk air cooler is equivalent to an additional electrical cost of up to R1.8 million per year [23], [24].

The under-prediction of underground temperatures would result in under-predicting the cooling requirements. If environmental standards are not met because of under-cooling, the mine can be forced to terminate all work in areas that exceed the temperature standards. The gold mine in this study has an average daily revenue of R4 million. The termination of underground workings would therefore lead to substantial financial losses.

The improved prediction of underground temperatures with transient simulations would result in better life-of-mine planning and optimisation. When paired with Industry 4.0 real-time climatic monitoring systems, this opens the doors to other applications. Some of these applications include ventilation-ondemand, live predictive modelling, and dynamic heat load management.

\section{CONCLUSION}

The literature points to the need to apply a transient simulation to an entire underground mine ventilation system. The objective of this study was to develop a transient model of an entire underground mine ventilation system. This transient model needed accurately to represent the ventilation system and its sensitivity to fluctuating ambient conditions.

A PTB simulation was successfully applied to a gold mine in Free State Province, South Africa. The transient simulation incorporated complex heat exchange processes and the sensitivity of an underground mine ventilation system to varying ambient conditions.

The results showed that the transient analysis improved the predictions of the underground environment compared with traditional steady-state analysis. The transient simulation had an error of $0.30^{\circ} \mathrm{C}$ for the DB temperature and $0.27^{\circ} \mathrm{C}$ for the WB temperature when predicting the limiting underground conditions. Steady-state analysis had an error of $2.54^{\circ} \mathrm{C}$ for the DB temperature and $1.42^{\circ} \mathrm{C}$ for the WB temperature for the same prediction.

Improved predictions allow for the improved management of mine ventilation systems. This is especially true for mine ventilation planning and optimisation, as they depend on the accurate prediction of underground temperatures.

This study was applied to a gold mining case study. Applying this study to underground mines with different depths, infrastructure, and geographical locations or in different seasons would give further insight into complex mine ventilation systems simulation. This would also give further indications of the sensitivity that mine ventilation systems have to different parameters.

\section{REFERENCES}

[1] J. J. L. du Plessis, Ventilation and occupational environment engineering in mines, 3rd ed., Johannesburg: Mine Ventilation Society of South Africa, 2014.

[2] J. C. Tien, "Chapter 9 - Mine ventilation systems," in Practical Mine Ventilation Engineering, no. 1, Intertec Pub., 1999 , pp. 167-189.

[3] Mine Health and Safety Council, Mine Health and Safety Act 29 of 1996 and Regulations, no. 29. South Africa, 2018, p. 199-203. 
[4] K. Carpenter, P. Roghanchi, and K. C. Kocsis, "Investigating the importance of climatic monitoring and modeling in deep and hot US underground mines," in Proceedings of 15th North American Mine Ventilation Symposium, 2015, pp. 1-4.

[5] S. Bluhm, R. G. Moreby, F. von Glehn, and C. Pascoe, "Life-of-mine ventilation and refrigeration planning for resolution copper mine,” J. South. African Inst. Min. Metall., vol. 114, no. 6, pp. 497-503, 2014.

[6] D. Nell, E. H. Mathews, and P. Mare, "Industry 4.0 roll-out strategy for dynamic mine heat load management," South African J. Ind. Eng., vol. 30, no. 3, pp. 106-114, 2019.

[7] J. Prinsloo, J. Vosloo, and E. H. Mathews, "Towards Industry 4.0: A roadmap for the South African heavy industry sector," South African J. Ind. Eng., vol. 31, no. 3, pp. 174-186, 2019.

[8] A. Ryan and D. S. Euler, "Heat stress management in underground mines," Int. J. Min. Sci. Technol., vol. 27, no. 4, pp. 651-655, 2017, doi: https://doi.org/10.1016/j.ijmst.2017.05.020.

[9] C. Gherghel and E. De Souza, "Ventilation requirements for uranium mines," in 12th US/North American Mine Ventilation Symposium, pp. 65-70, 2008.

[10] A. J. H. Nel, J. C. Vosloo, and M. J. Mathews, "Evaluating complex mine ventilation operational changes through simulations,” J. Energy South. Africa, vol. 29, no. 3, pp. 22-32, 2018.

[11] C. Stewart, S. M. Aminossadati, M. S. Kizil, and T. Andreatidis, "Diurnal thermal flywheel influence on ventilation temperatures in large underground mines," in 16th North American Mine Ventilation Symposium, pp. 9.1-9.8, 2017.

[12] P. Roghanchi, K. C. Kocsis, G. Danko, and A. Powell, "Underground climatic monitoring and modeling: Are we missing something?" Qual. - Access to Success, vol. 18, no. S1, pp. 133-139, 2017.

[13] M. S. Morar, S. M. Radu, D. Cioclea, and I. Gherghe, "Use of IT equipment and specialized programs for solving ventilation networks," Qual. - Access to Success, vol. 18, no. S1, pp. 121-126, 2017.

[14] S. Bluhm and H. Smit, "Important basics of mine ventilation and cooling planning," Mine Vent. Soc. South Africa, vol. 57, no. 1, pp. 15-24, 2004.

[15] I. Mathews, E. H. Mathews, J. H. van Laar, W. Hamer, and M. Kleingeld, "A simulation-based prediction model for coal-fired power plant condenser maintenance," Appl. Therm. Eng., vol. 174, pp. 1-10, 2020, doi: https://doi.org/10.1016/j.applthermaleng.2020.115294.

[16] K. A. Scalise, M. B. Teixeira, and K. C. Kocsis, "Managing heat in underground mines: The importance of incorporating the thermal flywheel effect into climatic modeling," Mining, Metall. Explor., vol. 38, no. 1, pp. 575579, 2021, doi: https://doi.org/10.1007/s42461-020-00323-5.

[17] P. Roghanchi and K. C. Kocsis, "Quantifying the thermal damping effect in underground vertical shafts using the nonlinear autoregressive with external input (NARX) algorithm,” Int. J. Min. Sci. Technol., vol. 29, no. 2, pp. 255262, 2018, doi: https://doi.org/10.1016/j.ijmst.2018.06.002.

[18] G. L. Danko, "Subsurface flow and transport process model for time dependent mine ventilation simulations," Trans. Institutions Min. Metall. Sect. A Min. Technol., vol. 122, no. 3, pp. 134-144, 2013, doi: https://doi.org/10.1179/147490013X13639459465691.

[19] F. H. von Glehn and I. Ox, "Monitoring and control of underground ventilation systems using VUMA-network," in Proceedings of the 10th US/North American Mine Ventilation Symposium, pp. 16-19, 2004.

[20] N. J. Smit, "Reducing electrical costs for a mine ventilation system with the aid of simulation software," Master's dissertation, Department of Electrical and Electronic Engineering, North-West University, 2017.

[21] B. M. Friedenstein, C. Cilliers, and J. van Rensburg, "Simulating operational improvements on mine compressed air systems," South African J. Ind. Eng., vol. 29, no. 3, pp. 69-81, 2018, doi: https://doi.org/10.7166/29-3-2049.

[22] D. Nell, "Optimising production through improving the efficiency of mine compressed air networks with limited infrastructure," Master's dissertation, Department of Mechanical Engineering. North-West University, 2017.

[23] G. E. du Plessis, "A variable water flow strategy for energy savings in large cooling systems", PhD dissertation, Department of Mechanical Engineering, North-West University, 2013.

[24] Eskom Ltd, Tariffs \& charges booklet 2021/2022, 2021. [Online]. Available: https://www.eskom.co.za/CustomerCare/TariffsAndCharges/Pages/Tariffs_And_Charges.aspx. 